\title{
An Investigation of the Relationship between Unplanned Buying and Post-purchase Regret
}

\author{
Mahmoud Abdel Hamid Saleh ${ }^{1}$ \\ ${ }^{1}$ Department of Marketing, College of Business Administration (CBA), King Saud University (KSU), Riyadh, \\ Kingdom of Saudi Arabia \\ Correspondence: Mahmoud Saleh, Department of Marketing, College of Business Administration, King Saud \\ University, P.O. Box 2459, Riyadh 11451, Kingdom of Saudi Arabia. E-mail: mhamid40@hotmail.com or \\ mahsaleh@ksu.edu.sa
}

Received: April 4, 2012 Accepted: May 7, 2012 Online Published: July 25, 2012

doi:10.5539/ijms.v4n4p106 URL: http://dx.doi.org/10.5539/ijms.v4n4p106

\begin{abstract}
The purpose of this study is to investigate the association of unplanned buying with post-purchase regret, moderated by consumer-family income and gender, as well as the association of both sales promotion and bankcard payment with unplanned buying in the Saudi market. Drawing on unplanned buying and post-purchase literature, the study tested a model of post-purchase regret. A survey was conducted among Saudi consumers of retail stores in Riyadh, Saudi Arabia. A convenience sample of 927 respondents was taken for data collection, among them 903 were finalized for analysis. The study concluded that there is a positive relationship between unplanned buying and post-purchase regret. An increased association of unplanned buying with post-purchase regret has been found among low-income earners and male consumers. Furthermore, bank-card payment, but not sales promotion, has a significant association with unplanned buying. Practically, consumers and marketers can benefit from the results and recommendations of this study, both avoiding the bad consequences of post-purchase regret. Self-awareness of the factors that cause regret may turn consumers to be more rational in their future buying decisions. Marketers' perceptions of those factors may also be helpful in setting marketing strategies towards their target markets; satisfying, and retaining consumers. The original contribution of this study comes from a lack of research in the Middle East on unplanned buying, post-purchase regret and their relationship antecedents.
\end{abstract}

Keywords: unplanned buying, impulsive buying, compulsive buying, post-purchase regret, post-purchase remorse, cognitive dissonance, sales promotion, bank cards, credit cards, demographics

\section{Introduction}

In contemporary markets, the multiplicity of alternative brands has contributed to consumers' confusion when making purchasing decisions (Shanker, Cherrier, and Canniford, 2006; Simpson, Siguaw, and Cadogan, 2008). In their quest to satisfy their needs, consumers tend, rationally, to use their limited resources in order to achieve maximum possible levels of satisfaction. More involvement is required by consumers in the purchasing-decision-making process so that they select the most suitable alternatives for them (Zeelenberg \& Pieters, 2007). This can be done when consumers precisely set their goals as a basis of the alternative-selection process (Bui, 2011).

Despite the pursuit of consumers to rationalize their purchasing decisions, they may be in doubt to what extent their decisions were correct. Consumers compare the brands they bought with the alternatives they had decided not to buy (Loomers and Sugden, 1982; Landman, 1987; Boles \& Messick, 1995; Shanker et al., 2006; Simpson et al., 2008). The result of such comparison is often a state of grief and psychological pain known as post-purchase regret or cognitive dissonance. When consumers perceive that their purchasing decisions were wrong, they feel regret (Landman, 1987; Tsiros \& Mittal, 2000; Heitmann, Lehmann, and Herrmann, 2007). Post-purchase regret is powerful enough to make consumers make illusions (Balcetis \& Dunning, 2007). However, it is not necessary that all purchases lead to regret (Sweeney, Hausknecht, and Souter, 2000).

Post-purchase regret is not favorable to marketers whose consumers purchased their brands and regret about them. The consumer behavior literature shows that post-purchase regret is accompanied by low-consumer satisfaction (Inman, Dyer, and Jia, 1997; Taylor \& Scheider, 1998; Tsiros \& Mittal, 2000). Low satisfaction 
leads to no repurchase intention (Tsiros \& Mittal, 2000), a tendency to shift to alternative brands (Zeelenberg \& Pieters, 1999; Bui, 2011; Garcia \& Perez, 2011), and negative word-of-mouth about the brand (Garcia \& Perez, 2011). Therefore, knowing the antecedents that lead to consumers' regret, after making a purchase, is important to marketers. Consumers' consent of a brand is a first step toward brand loyalty; hence, establishing long-run business relationships with them (Bui et al., 2011).

Because of the negative consequences of post-purchase regret on both consumers and marketers, it is important that marketers understand the factors that are associated with consumers' sentiment of post-purchase regret and try to alleviate the consumers' psychological regret sufferings of sorrow and pain. On the other hand, marketers should work to strengthen the competitive positioning of their brands, and increase consumers loyalty. If a marketer does not interfere to reduce post-purchase regret of his brand, consumers will be an easy prey for his lurking competitors. The competitors' efforts that are needed to convert consumers' loyalty to their brands will be much less at the stage of post-purchase regret (George and Yaoyuney, 2010).

Unplanned buying from retailers is a common human behavior. Retailers are well aware that a sizable portion of their sales volume is generated by impulsive buying, with over $50 \%$ of mall shoppers' buying items and $70 \%$ of grocery items (Underhill, 1999; Nicholas, Li, Roslow, Kranendonk, and Mandakovic, 2001). Once unplanned buyers enter retail environments, they place themselves in contexts to be appealing to all the senses (Pooler, 2003). Many studies have demonstrated a direct positive relationship between unplanned buying and post-purchase regret (Hoch \& Loewentein, 1991; Wood, 1998; George and Yaoyuneyong, 2010). In this context, the researcher of the current study conducted an exploratory study on a convenience sample of 160 of undergraduate and postgraduate students at King Saud University, using group-discussions in classrooms. The researcher asked them about post-purchase regret and unplanned buying, as well as some associated factors. Findings of this initial research revealed that unplanned buying from retailers is a behavior experienced by Saudi consumers. The average rate of unplanned buying exceeds $30 \%$ of the total value of retail purchases. Some students saw unplanned buying as a negative behavior that leads to an imbalance in the structure of consumers spending, and sometimes accompanied by regret. Few of them expressed pleasure in practicing this type of purchase. However, the researcher did not find a common sense among students regarding the association of some other factors (consumer's gender, consumer's family income per month, retailers' sales promotion and consumer's bank-card payment) with unplanned buying or post-purchase regret and their relationship.

Accordingly, this study, as a pioneering study in the Saudi market, has four specific objectives: first, to investigate the association of unplanned buying with post-purchase regret and the factors that influence their expected relationship, second, to suggest marketing strategies to overcome the negative effects of post-purchase regret feelings on the part of consumers, third, to raise the Saudi consumers' awareness of the means that could reduce their unplanned buying and post-purchase regret, and fourth, to direct Saudi officials find mechanisms to control the major antecedents of consumers' post-purchase regret and its negative consequences on both marketers and consumers.

\section{Literature Review and Study Hypotheses}

The behavior of consumer sentiment of post-purchase regret received global attention by marketers and researchers. Researchers tried to identify the dimensions and causes of post-purchase regret as well as its impact on consumers' satisfaction and repurchasing intention. This section reviews the literature on the variables of unplanned buying and post-purchase regret and their relationship moderated by consumer's family income and gender. It also reviews the association of both sales promotion and the consumers' usage of their bank cards in payment at retail stores with unplanned buying, the factors that have been initially involved and expected to have associations with the current study's main variables depending on the results of its exploratory study.

\subsection{Unplanned Buying and Post-purchase Regret}

Some researchers defined the concept and characteristics of the purchase which is not planned. Solomon (2002) classified it into three categories: 1- Unplanned buying, which happens when the consumer is not familiar with the layout of the store, under pressure of time, or when he remembers his need of something in the store. 2Impulsive buying, which is a state of urgency to buy, a consumer cannot resist. 3- Compulsive buying, as a result of consumer's frequent visits to the stores because of his sense of boredom, distress or anxiety. Later, he distinguished between compulsive buying and impulsive buying on the ground that impulsive buying focuses on a particular product at a given moment whereas compulsive buying is a continuous purchase centered on the buying process itself, and not on purchased goods (Solomon, 2004). Others saw that compulsive buying is a process of chronic purchase that comes as a reaction to events and negative feelings (Faber \& O'Guinn, 1992). 
In spite of attempts to distinguish between the three terms of the purchase which is not planned, some researchers used them interchangeably. Impulsive buying was defined as an unplanned or spontaneous purchase (Rook \& Fisher, 1995) or a purchase with no intention to buy before entering the store (Engel, Blackwell, and Kollat, 1982), meaning an unplanned buying. Compulsive buying was also defined as a rush of purchase that cannot be resisted and accompanied by a state of tension and unconsciousness (Muller, Reinecker, Jacobi, Reisch, and De Zawaan, 2005). Generally, three characteristics were determined for compulsive buying: consumer's irresistible desire to buy, consumer's ungoverned behavior to buy, and continuation of the consumer's purchase despite its possible negative consequences on him, personally, socially, professionally, and financially (Dittmar,Long, and Bond, 2007).

Compulsive buying has its effects when consumers lose their control over purchase. Once it happens, consumers will buy unnecessary goods or more than they can afford to spend. Compulsive buying is accompanied by some cognitive aspects including lack of planning and deliberation, and some affective aspects such as pleasure and excitement, compulsion, lack of control, and probability of feeling regret (Verplanken \& Herabadi, 2001). Under these circumstances, purchasing power is due to the feelings of excitement and pleasure that are not associated with planned buying (Lee \& Yi., 2008). Some researchers saw that the source of pleasure and fun is not the product that is purchased impulsively, but the buying process itself (O'Guinn \& Faber, 1989).

Numerous studies examined the impact of unplanned buying on consumer's post-purchase regret. Wood (1998) reviewed the literature of this relationship and concluded that most cases of unplanned buying led to regret and anger. Hoch \& Loewentein (1991) concluded that impulsive buying, that comes from consumer's low involvement in purchasing decision, leads to a sense of post-purchase regret. Converlely, a study proved an adverse relationship between impulsive buying and post-purchase regret, where impulsive buyers were less regretful compared to buyers who planned their purchases. The logic behind is that a consumer who did not get used to unplanned buying feels sorry more than a consumer who is accustomed to this behavior (George and Yaoyuneyong, 2010).

Thus, despite some studies differentiated between unplanned buying, impulsive buying and compulsive buying, the researcher found no common agreement on this distinction, and sometimes they were used interchangeably. The current study adopts the use of unplanned buying to express all types of purchases in instantaneous situations. However, most of the previous studies refer to the positive impact of unplanned buying on post-purchase regret. Accordingly, hypothesis 1 is proposed as follows:

H1. Unplanned buying has a significant positive association with post-purchase regret.

\subsection{Demographics and Post-purchase Regret}

Differences among shoppers are of great interest for marketers' targeting and the setting of marketing strategies. Regarding the income effect on the relationship between unplanned buying and post-purchase regret, the researcher did not find many studies. Some studies found that students who had parents with higher income were less likely to be compulsive buyers (Norum, 2008). On the contrary, other studies found that income has positively influenced impulsive buying (Mai, Jung, Lantz, Garold and Loeb, 2003; Mitchill, 2004). It is believed that high-income consumers are better able to tolerate financial losses (Bauer, 1960). As regards post-purchase regret, cognitive dissonance has been confirmed at low-income consumers of grocery products because they are more sensitive to sales promotion than consumers with higher incomes (Gbadamosi, 2009). Therefore, the current study investigates the association of family income as a moderator of the relationship between unplanned buying and post-purchase regret. Accordingly, hypothesis 2 is proposed as follows:

H2. Unplanned buying will be positively associated more with low-income consumers' post-purchase regret, than both middle-income consumers and high-income consumers.

Past research investigated the impact of gender on unplanned buying, but not on post-purchase regret. Generally, female's purchasing behavior is thought of as being more emotional than males, suggesting that they are more responsive to impulsive buying (Coley \& Burgess, 2003). Researchers found that females were practicing this type of purchase more than males (Roberts, 1998; Coley \& Burgess, 2003, Shoham \& Brencic, 2003; Yurchisin \& Johnson, 2004; Lin \& Lin, 2005; Muller et al., 2007; Norum, 2008; Lai, 2010). This was attributed to females' propensity to shopping more than males (Rook \& Hoch, 1985; Dittmar, Beattie, and Friese, 1996). However, few studies have found that males were practicing unplanned buying more than females (Cobb \& Hoyer, 1986; Block \& Morwitz, 1999). As regards the effect of gender as a moderator of the relationship between unplanned buying and post-purchase regret, a study revealed that females were more likely than males to exhibit feelings of regret over making an impulsive buying (Coley \& Burgess, 2003). Considering the finding of this study, hypothesis 3 is proposed as follows: 
H3. Unplanned buying will be associated more with females' post-purchase regret than males.

\subsection{Sales Promotion and Unplanned Buying}

Sales promotion was defined as activities aimed at urging specific targeted market segments to buy the products (Blattberg \& Nelsin, 1990; Berman \& Evans, 1995; d'Astous \& Landreville, 2003; S. Peattie \&K. Peattie, 2003; Brassington \& Peattie, 2006). Those activities were often classified into two types: monetary and non-monetary activities (Kowok \& Unccles, 2005). Monetary activities are directly related to price discounts such as: coupons, discounts, and shelf-price discounts, whereas non-monetary activities are related indirectly to price discounts such as: free gifts and buy-one-get-one-free (BOGOF) offers.

With regard to the relative importance of sales promotion methods in terms of their impact on purchasing decisions, consumers respond more to price discounts, buy-one-get-one-free and coupons (Shi Ceung, and Prendergast, 2005). One study revealed that price discounts, free samples, extra units to the purchased units and in-store displays were the methods with significant effect on consumer's willingness to buy the product, whereas coupons have no significant effect (Ndubisi \& Moi, 2005). Another study found that supermarket buyers in the UK are more likely to use four ways of sales promotion: coupons, price discounts, free samples of the product and buy-one-get-one-free, followed by discounts, free samples and coupons (Gilbert \& Jackaria, 2002).

Regarding the impact of sales promotion on unplanned buying, a study revealed a positive relationship between retail displays and impulsive buying of cigarettes, to the extent that $38 \%$ of those who tried to give up smoking within 12 month and $33.9 \%$ of those who have recently given up smoking returned once again to buy cigarettes because of commercial offerings (Wakefield, Germain, and Henriksen, 2008). For cigarettes, too, another study concluded that the point-of-sale displays have increased consumers' unplanned buying fourfold. The study attributed it to the fact that point-of-sale displays play the role of advertising that encourages consumers to buy items they do not plan to buy before entering the store (Carter, Mills, and Danon, 2009).

In this context, another study concluded that the use of sales promotion strategy, particularly the Instant-reward promotion, has a significant positive influence on unplanned buying. It also concluded that some associated factors such as attractive packages and price discounts increase unplanned buying by consumers (Liao, Shen, and Chu, 2009). Mihic \& Kursan (2010) examined the impact of some situational factors on unplanned buying, including: sales promotion, efficiency of salesmen, and the location of the shop. They found that the most influential factor on unplanned buying was on-sale displays.

Thus, past research indicates a positive association of sales promotion with unplanned buying, especially with the use of price discounts, free samples, and buy-one-get-one free. Accordingly, hypothesis 4 is proposed as follows:

H4. Sales promotion has a significant positive association with unplanned buying.

\subsection{Bank-card Payment and Unplanned Buying}

Several studies have addressed the impact of the use of consumers' bank cards to pay for purchases on the volume of expenditure, sales, unplanned buying, and consumer's valuation of product prices. There is evidence that the use of bank cards increases consumer spending (Feinberg, 1986). Consumers who regularly use credit cards to pay for their purchases spend more compared to those who use other means of payment, and they even tend to exceed their capability to pay (Ritzer, 1995; Pirog \& Robers, 2007). As for reflection of the use of bank cards on the volume of sales, a study revealed that the use of credit cards in fast food restaurants increased sales volume and the number of purchase transactions between 50\%-100\% compared to cash transactions (Ritzer, 1995). Besides, using credit cards allows consumers to experience a style of life beyond their immediate financial capability (Hoyer and McInnis, 2001; Cohen, 2007; Pirog, 2007). Young shoppers who have a tendency towards unplanned buying have a higher probability to become debtors because of their usage of credit cards in the purchasing processes (Wang \& Xiao, 2009). In addition, credit card users are less sensitive to product prices (Takunga, 1992; Roberts \& Jones, 2001), and they tend to buy products with high prices (Deshpande \& Krishnan, 1980).

Research on the relationship between the usage of bank cards in payment and unplanned buying showed a positive relationship between the usage of credit cards and unplanned purchase (Roberts, 1998; Roberts \& Martines, 1997; Roberts \& Jones, 2001; Phau \& Woo, 2008). Impulsive-buying consumers have credit cards more than other consumers (O'Guinn \& Faber, 1989; d'Atous, 1990; Magee, 1994; Park and Burns, 2005). Using credit cards eliminates consumer's need for money and increases the likelihood to unplanned buying. In this context, some researchers saw that the problem of unplanned buying has increased due to the accelerating growth in marketing credit cards and availing them easily to university students (Coulton, 1996; Mannix, 1999; 
Schenbari, 2000). The reason behind the rapid growth of credit-card usage was attributed to intense competition among banks for increasing their share of the credit-card market, hence, making it easier for many consumers to obtain credit cards and use them in purchasing (Phau \& Woo, 2008).

Thus, previous studies revealed a positive impact of using bank cards on unplanned buying. They focused on the impact of credit-card usage on unplanned buying. The current study considers using the term bank cards to cover both credit cards and ATM cards of consumer's personal accounts, especially in the Saudi market. ATM cards play a role as important as credit cards with Saudi consumers, and perhaps more; since many Saudis enjoy prosperous life styles. Accordingly, hypothesis 5 is proposed as follows:

H5. Bank-card payment has a significant positive association with unplanned buying.

\section{Study Proposed Model}

Depending on the literature review and derived hypotheses, the researcher depicts the study's proposed model as shown at figure 1 . The relationships of this model will be tested as a basis of the study findings, analysis and recommendations.

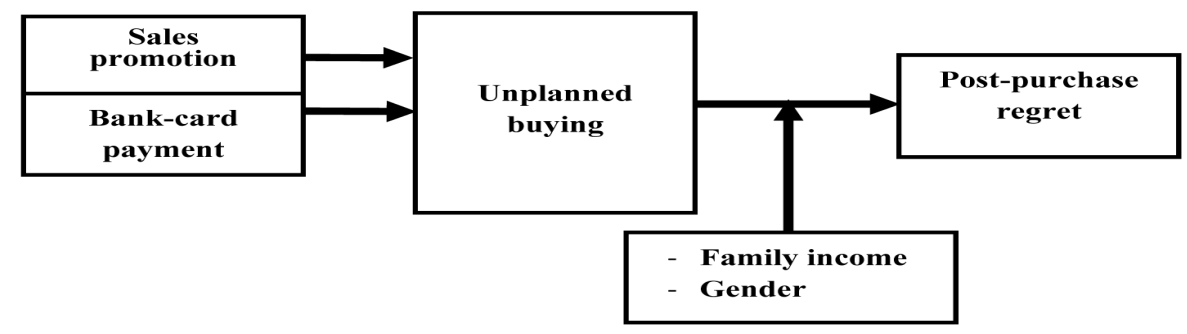

Figure1. Proposed research model

\section{Methodology}

\subsection{Sample and Data Collection}

One thousand questionnaires were distributed to a convenience sample of Saudi consumers in Riyadh city. A total of 927 filled questionnaires were received, of which 24 were invalid and excluded from the analysis. Therefore, a total of 903 valid questionnaires were eventually entered into the analysis, representing a response rate of $90.3 \%$ of the distributed questionnaires.

Table 1 shows frequencies and percentages of study sample characteristics, categorized by monthly family income and gender. Low-income consumers represent $46.2 \%$ of the study sample, whereas middle-income consumers represent $41.2 \%$ and high-income consumers represent $12.6 \%$. Male consumers represent $71.5 \%$ of the study sample, whereas female consumers represent $28.5 \%$.

Table 1. Characteristics of study sample

\begin{tabular}{lll}
\hline & frequencies & $\%$ \\
\hline Family Income (per month) & & \\
$\quad$ Less than S.R. 10000 (low) & 417 & 46.2 \\
10000-25000 (middle) & 372 & 41.2 \\
$\quad$ More than 25000 (high) & 114 & 12.6 \\
Total & 903 & 100 \\
Gender & & \\
$\quad$ Male & 646 & 71.5 \\
$\quad$ Female & 257 & 28.5 \\
Total & 903 & 100 \\
\hline
\end{tabular}




\subsection{Measures}

Unplanned buying was measured by a scale of (9 items) depending on the scale used by Lin \& Lin (2005) and Phau \& Woo (2008). Post-purchase regret was measured by the scale of (4 items) used by Bui (2011). Sales promotion was measured by the scale of (6 items) used by Gbadmosi (2009), Ndubisi \& Moi (2005) and Shi et al. (2005). Bank-card payment (8 items) was measured using the scale by Roberts \& Jones (2001) and Phau \& Woo (2008). The questionnaire contained 23 Likert-type items, each item was measured by five-point scale ranging from " $1=$ strongly disagree" to " $5=$ strongly agree".

\section{Findings}

\subsection{Preliminary Data Analysis}

Data analysis was performed using SPSS to test the validity and reliability of the survey. Validity has been tested by Factor Analysis to identify suitable variables' related items and Reliability has been tested by the internal consistency method (Cronbach's Alpha coefficient).

Table 2. Factor loading of measured items

\begin{tabular}{|c|c|c|c|c|}
\hline Items & $\begin{array}{l}\text { Post-purchase } \\
\text { regret }\end{array}$ & $\begin{array}{l}\text { Unplanned } \\
\text { buying }\end{array}$ & $\begin{array}{l}\text { Sales } \\
\text { promotion }\end{array}$ & $\begin{array}{l}\text { Bank-card } \\
\text { payment }\end{array}$ \\
\hline $\begin{array}{l}\text { I often feel anxiety after buying goods I have not } \\
\text { planned before entering the store. }\end{array}$ & 0.82 & - & - & - \\
\hline $\begin{array}{l}\text { I often feel that my unplanned purchases have little } \\
\text { benefits. }\end{array}$ & 0.78 & - & - & - \\
\hline $\begin{array}{l}\text { I often try to convince myself that the goods I have } \\
\text { bought impulsively may benefit later on. }\end{array}$ & 0.69 & - & - & - \\
\hline $\begin{array}{l}\text { My planned purchases make me more satisfied than } \\
\text { unplanned purchases. }\end{array}$ & 0.74 & - & - & - \\
\hline $\begin{array}{l}\text { When I go to the store, I buy a lot of goods I did not } \\
\text { plan to buy in advance. }\end{array}$ & - & 0.50 & - & - \\
\hline $\begin{array}{l}\text { When I see goods in the store, I buy immediately } \\
\text { without thinking if I really need or not. }\end{array}$ & - & 0.60 & - & - \\
\hline $\begin{array}{l}\text { When I hesitate to buy some goods inside the store, } \\
\text { I say to myself Buy now and think later. }\end{array}$ & - & 0.57 & - & - \\
\hline Sometimes I feel that I buy some goods impulsively. & - & 0.54 & - & - \\
\hline $\begin{array}{l}\text { Sometimes I feel a lack of interest of some goods } \\
\text { that I bought. }\end{array}$ & - & 0.74 & - & - \\
\hline I Often buy some goods do not really need. & - & 0.75 & - & - \\
\hline I usually buy things I do not buy ordinarily. & - & 0.67 & - & - \\
\hline I often buy goods and wonder why I bought them. & - & 0.73 & - & - \\
\hline I often buy goods and do not use them at all. & - & 0.69 & - & - \\
\hline $\begin{array}{l}\text { I often find surprising price discounts when visiting } \\
\text { retail stores. }\end{array}$ & - & - & 0.62 & - \\
\hline $\begin{array}{l}\text { Stores I visit always give free samples of some } \\
\text { goods. }\end{array}$ & - & - & 0.73 & - \\
\hline $\begin{array}{l}\text { When visiting stores, I always find contests for } \\
\text { those who exceed a certain purchase value. }\end{array}$ & - & - & 0.71 & - \\
\hline $\begin{array}{l}\text { Stores always distribute prizes to those who exceed } \\
\text { a certain limit of purchase value. }\end{array}$ & - & - & 0.78 & - \\
\hline $\begin{array}{l}\text { Stores always provide several types of goods in one } \\
\text { package at reduced prices. }\end{array}$ & - & - & 0.76 & - \\
\hline $\begin{array}{l}\text { At purchasing, I visit stores I know they give price } \\
\text { discounts on some products. }\end{array}$ & - & - & 0.79 & - \\
\hline $\begin{array}{l}\text { When I go to the store, I find myself buy things } \\
\text { without previous intention to buy. }\end{array}$ & - & - & - & - \\
\hline $\begin{array}{l}\text { When I see some goods in the store, I buy them } \\
\text { without thinking if I really need or not. }\end{array}$ & - & - & - & - \\
\hline
\end{tabular}




$\begin{aligned} & \text { I often use my banking cards to pay for my - } \\
& \text { purchases from retail stores. }\end{aligned}$
$\begin{aligned} & \text { I become less interested in prices when using a bank } \\
& \text { card in purchasing process. }\end{aligned}$
$\begin{aligned} & \text { My banking cards encourage me to repeat my visits }- \\
& \text { to retail stores for purchase. }\end{aligned}$
$\begin{aligned} & \text { My banking cards encourage me not to put limits on } \\
& \text { the value of my purchases from stores. }\end{aligned}$
$\begin{aligned} & \text { Banking cards are easier to be kept compared to - } \\
& \text { cash money. }\end{aligned}$
\begin{tabular}{l} 
Banking cards are safer than keeping cash money. \\
\hline
\end{tabular}

As shown in table 2, Using principal extraction and Varimax rotation methods, validity testing findings for the items of the study instrument demonstrated high loading coefficients. The loading coefficient for each item exceeds a factor loading accepted benchmark of 0.50 (Churchill, 1979) except the last two items related to bank-card payment. These two items have been excluded from statistical reliability, descriptive and analytical analysis of hypotheses testing.

Table 3. Reliability of study variables

\begin{tabular}{lll}
\hline Variables & No. of items & $\begin{array}{l}\text { Reliability } \\
\text { (Cronbach's } \infty)\end{array}$ \\
\hline Post-purchase regret & 4 & 0.678 \\
Unplanned buying & 9 & 0.856 \\
Sales promotion & 6 & 0.794 \\
Bank-card payment & 4 & 0.652 \\
\hline
\end{tabular}

As shown in table 3, Reliability testing of the study measuring variables demonstrated acceptable levels of reliability with Alpha coefficients. All Alpha coefficients have exceeded the minimum accepted value of 0.60 (Malhotra, 2007).

Table 4. Descriptive analysis of study variables

\begin{tabular}{|c|c|c|c|}
\hline Variables & Mean & $\begin{array}{l}\text { Standard } \\
\text { deviation }\end{array}$ & $\begin{array}{l}\text { Coefficient } \\
\text { of variation }\end{array}$ \\
\hline Post purchase regret & 3.30 & 0.79 & 0.24 \\
\hline $\begin{array}{l}\text { I often feel anxiety after buying goods I have not planned } \\
\text { before entering the store. }\end{array}$ & 3.15 & 1.29 & 0.41 \\
\hline $\begin{array}{l}\text { I often feel that my not unplanned purchases have little } \\
\text { benefits. }\end{array}$ & 2.96 & 1.22 & 0.41 \\
\hline $\begin{array}{l}\text { I often try to convince myself that the goods I have bought } \\
\text { impulsively may benefit later on. }\end{array}$ & 3.08 & 1.21 & 0.39 \\
\hline $\begin{array}{l}\text { My planned purchases make me more satisfied than unplanned } \\
\text { purchases. }\end{array}$ & 3.78 & 1.21 & 0.32 \\
\hline Unplanned buying & 2.94 & 0.91 & 0.31 \\
\hline $\begin{array}{l}\text { When I go to the store I buy a lot of goods I did not plan to buy } \\
\text { in advance. }\end{array}$ & 3.47 & 1.27 & 0.37 \\
\hline $\begin{array}{l}\text { When I see goods in the store, I buy immediately without } \\
\text { thinking if I really need or not. }\end{array}$ & 2.74 & 1.34 & 0.49 \\
\hline $\begin{array}{l}\text { When I hesitate to buy some goods inside the store, I say to } \\
\text { myself Buy now and think later. }\end{array}$ & 2.34 & 1.31 & 0.56 \\
\hline Sometimes I feel that I buy some goods impulsively. & 2.78 & 1.28 & 0.46 \\
\hline Sometimes I feel a lack of interest of some goods that I bought. & 2.88 & 1.19 & 0.41 \\
\hline I often buy some goods I do not really need. & 2.75 & 1.31 & 0.47 \\
\hline I usually buy things I do not buy ordinarily. & 2.88 & 1.32 & 0.46 \\
\hline
\end{tabular}




\begin{tabular}{|c|c|c|c|}
\hline I often buy goods and wonder why I bought them. & 2.61 & 1.34 & 0.51 \\
\hline I often buy goods and do not use them at all. & 2.39 & 1.38 & 0.58 \\
\hline Sales promotion & 3.14 & 0.86 & 0.27 \\
\hline $\begin{array}{l}\text { I often find surprising price discounts when visiting retail } \\
\text { stores. }\end{array}$ & 3.43 & 1.28 & 0.37 \\
\hline Stores I visit always give free samples of some goods. & 2.80 & 1.24 & 0.44 \\
\hline $\begin{array}{l}\text { When visiting stores, I always find contests for those who } \\
\text { exceed a certain purchase value. }\end{array}$ & 2.91 & 1.25 & 0.43 \\
\hline $\begin{array}{l}\text { Stores always distribute prizes to those who exceed a certain } \\
\text { limit of purchase value. }\end{array}$ & 2.89 & 1.22 & 0.42 \\
\hline $\begin{array}{l}\text { Stores always provide several types of goods in one package at } \\
\text { reduced prices. }\end{array}$ & 3.19 & 1.16 & 0.36 \\
\hline $\begin{array}{l}\text { At purchasing, I visit stores I know they give price discounts on } \\
\text { some products. }\end{array}$ & 3.60 & 1.20 & 0.33 \\
\hline Bank-card payment & 2.86 & 0.98 & 0.34 \\
\hline $\begin{array}{l}\text { I often use my banking cards to pay for my purchases from } \\
\text { retail stores. }\end{array}$ & 3.31 & 1.33 & 0.40 \\
\hline $\begin{array}{l}\text { I become less interested in product price when using a bank } \\
\text { card in purchasing process. }\end{array}$ & 2.65 & 1.42 & 0.53 \\
\hline $\begin{array}{l}\text { My banking cards encourage me to repeat my visits to retail } \\
\text { stores for purchase. }\end{array}$ & 2.74 & 1.43 & 0.52 \\
\hline $\begin{array}{l}\text { My banking cards encourage me not to put limits on the value } \\
\text { of my purchases from stores. }\end{array}$ & 2.76 & 1.46 & 0.53 \\
\hline
\end{tabular}

Table 4 shows Means, standard deviations and coefficients of variation (C.V.) for all items in the measuring instrument. The overall mean of Saudi consumers' regret feelings on their purchases from retail stores is 3.30, which is slightly higher than 3 . Satisfaction with planned buying as compared to unplanned buying accounted for the largest mean and lowest C.V. among the four constituent items of post-purchase regret, with a mean of 3.78 and C.V. of 0.32 , followed by the anxiety feeling of unplanned buying with a mean of 3.15 and C.V. of 0.41 , then comes the consumer's trial to convince himself that the goods he bought may later benefit, with a mean of 3.08 and C.V. of 0.39 .

The overall mean of Saudi consumers' unplanned buying is 2.94, which is less than 3. Unplanned Purchase represents the largest item of unplanned buying, with a mean of 3.47 and C.V. of 0.37 , followed by a lack of interest of some purchased goods, with a mean of 2.88 and C.V. of 0.41 , then buying some things that are not ordinarily bought, with a mean of 2.88 and C.V. of 0.46 .

The overall mean for the variable "sales promotion" is slightly higher than 3 ; the mean is 3.14 . Consumer's keenness to visit stores that give price discount has the highest mean among sales promotion items, with a mean of 3.60 and C.V. of 0.33 , followed by finding surprising price discounts when visiting the store, with a mean of 3.43 and C.V. of 0.37 and then comes the provision of several types of goods in one package at reduced prices, with a mean of 3.19 and C.V. of 0.36 .

The overall mean for consumers' usage of bank cards in payment is less than 3 ; the mean is 2.86 . Saudi consumers' usage of banking cards in purchasing is the highest mean and the lowest C.V., with a mean of 3.31 and C.V. of 0.40 . Using bank cards encourages the consumer not to put limits on the value of purchases from stores comes next, with a mean of 2.76 and C.V. of 0.53 , then bank cards' ability to encourage consumers repeating their visits to the store, with a mean of 2.74 and C.V. of 0.52 .

\subsection{Tests of Hypotheses}

The testing findings of study hypotheses are shown in table 5 . 
Table 5. H1, $\mathrm{H} 2$ and $\mathrm{H} 3$ testing

\begin{tabular}{|c|c|c|c|c|}
\hline$H$ & Regression equation & $B$ & $R^{2}$ & $\Delta R^{2}$ \\
\hline \multirow[t]{2}{*}{$H 1$} & Unplanned buying & $0.279^{* *}$ & 0.078 & - \\
\hline & Unplanned buying & $0.270^{* *}$ & & 0012 \\
\hline \multirow[t]{3}{*}{$\mathrm{H}_{2}$} & Income & $0.108^{* *}$ & 0.090 & 0.012 \\
\hline & Unplanned buying $\mathrm{x}$ income & $-0.308^{* *}$ & 0.097 & 0.007 \\
\hline & Unplanned buying & $0.269^{* *}$ & 0.079 & 0.001 \\
\hline \multirow[t]{2}{*}{$H 3$} & Gender & -0.031 & & \\
\hline & Unplanned buying $\mathrm{x}$ gender & $0.441^{* *}$ & 0.092 & 0.014 \\
\hline
\end{tabular}

Table 5 demonstrates a strong support of the proposed relationship in $H 1$. H1 specifies a positive relationship between unplanned buying and post-purchase regret. $R^{2}$ of 0.078 means that unplanned buying explains about $8 \%$ of the variations in post-purchase regret and Beta $=0.279$ means that unplanned buying has a positive effect on post-purchase regret. Therefore, $H 1$ is upheld.

To examine the impact of consumer's family income per month and gender on the relationship between consumers' unplanned buying and their post-purchase regret $(H 2, H 3)$, the researcher used hierarchical regression as suggested by Aiken and West (1991), and Jaccard, Turrisi, and Wan (1990). The moderators, family income and gender, were coded as dummy variables before entering them into the regression model.

$H 2$ posits that unplanned buying will be positively associated with post-purchase regret at low-income consumers stronger than middle and high income consumers. We first regressed unplanned buying and income on post-purchase regret, which produced $R^{2}$ of 0.090 . When entering the interaction of unplanned buying by income into the regression, $R^{2}$ increased to 0.097 . The increase of 0.007 in $R^{2}$ was statistically significant ( $\mathrm{p}<$ $0.05)$.

$H 3$ posits that unplanned buying will be associated more with females' post-purchase regret than males. The study first regressed unplanned buying and gender on post-purchase regret, which produced $R^{2}$ of 0.079 . When entering the interaction of unplanned buying by gender into the regression, $R^{2}$ increased to 0.092 . The increase of 0.014 in $R^{2}$ was statistically significant $(\mathrm{p}<0.05)$.

Table 6. Regression coefficients of unplanned buying for income levels

\begin{tabular}{llll}
\hline & \multicolumn{2}{l}{ Post-purchase regret } & \\
\cline { 2 - 4 } & $\begin{array}{l}\text { Low-income } \\
\text { consumers }\end{array}$ & $\begin{array}{l}\text { Middle-income } \\
\text { consumers }\end{array}$ & $\begin{array}{l}\text { High-income } \\
\text { consumers }\end{array}$ \\
\cline { 2 - 4 } Unplanned buying & $0.387^{* *}$ & $0.205^{* *}$ & $0.131^{* *}$ \\
\hline
\end{tabular}

** Marginally significant at the $\mathrm{p} \leq 0.05$ level.

Further analysis (table 6.) shows that unplanned buying is positively associated with low-income consumers' post-purchase regret $(\beta=0.387)$ stronger than the middle-income consumers $(\beta=0.205)$ and the high-income consumers $(\beta=0.131)$, meaning that low-income consumers are the highest who sense post-purchase regret on their unplanned buying than both middle and high-income consumers. Thus, $H 2$ is upheld.

Table 7. Regression coefficients of unplanned buying for gender

\begin{tabular}{lll}
\hline \multirow{3}{*}{ Unplanned buying } & Post-purchase regret & \\
\cline { 2 - 3 } & Male & Female \\
\cline { 2 - 3 } & $0.294^{* *}$ & $0.053^{* *}$ \\
\hline
\end{tabular}

** Marginally significant at the $\mathrm{p} \leq 0.05$ level.

Further analysis (table 7.) shows that unplanned buying is positively associated with male consumers' post-purchase regret $(\beta=0.294)$ stronger than female consumers $(\beta=0.053)$, meaning that male consumers are sensing post-purchase regret on their unplanned buying more than female consumers. Thus, $\mathrm{H} 3$ is not supported. 
To examine $H 4$ and $H 5$, step-wise-multiple regression was used as shown in table 8.

Table 8. H4, H5 testing

\begin{tabular}{lllll}
\hline$H$ & Regression equation & $\beta$ & $p$ & $R^{2}$ \\
$H 4$ & Sales promotion & 0.056 & 0.065 & \multirow{2}{*}{0.188} \\
$H 5$ & Bank-card payment & $0.423^{* *}$ & 0.000 & \\
\hline Dependent variable measure: unplanned buying. & & & \\
$* *$ Marginally significant at the $\mathrm{p} \leq 0.05$ level. & & & \\
\hline
\end{tabular}

Table 8 shows that $H 4$ testing results do not specify a significant positive relationship between sales promotion and consumers' unplanned buying ( $p>0.05)$, whereas $H 5$ specifies a significant positive relationship between bank-card payment and unplanned buying $(\mathrm{p}<0.05)$. This means that consumers' usage of bank cards in their payment at retail stores makes them buy impulsively. The value of $R^{2}=0.188$ means that the variation of bank-card payment usage explains about $19 \%$ of variation in unplanned buying. Thus, the researcher rejected $H 4$ and accepted $H 5$.

\section{Discussion and Conclusion}

The main objective of this study was to investigate the association between unplanned buying and post-purchase regret, moderated by family income and gender, as well as the association of both sales promotion and bank-card payment with unplanned buying in the Saudi market. The research model has been built on the literature review of research in other markets. The results demonstrated a significant positive association of unplanned buying with post-purchase regret, validating the findings by Hoch \& Loewentein (1991), Wood (1998), and Verplanken \& Herabdi (2001). This result can be attributed to consumer's feeling of irrationality when buying impulsively, especially with low-income consumers, whose resources are limited. Irrationality leads to dissatisfaction regarding the consumer's wisdom in purchase decision making triggered by marketers. Dissatisfaction leads to post-purchase regret (Inman et al., 1997; Taylor \& Scheider, 1998; Tsiros \& Mittal, 2000). Consumers especially of low-income levels - have to manage their incomes in a more rational way. Planning expenditure will enable them to buy only products that satisfy their actual needs. Consumers should get used to increasing their degree of involvement in purchasing decisions. Preparing a list of the needed products and discussing them with family members before going to the store can reduce the probability of purchasing unplanned goods and post-purchase regret.

On contrast to what Coley \& Burgess (2003) found in their study, the current research demonstrated that males are more sensitive than females regarding post-purchase regret after unplanned buying. Post-purchase regret is larger for males than for females when buying impulsively. This can be attributed to a cultural aspect in the Saudi society, where shopping is a way of entertainment, especially for females. Females repeat their visits to the stores many times a week, thus; the likelihood of their unplanned buying is increased. Gradually, with the passage of time, they become accustomed to unplanned buying, feeling less regret about it (George and Yaoyuneyong, 2010). Emotional buying motives of females make them satisfied with the purchased products and do not think much about the irrationality of buying them. On the contrary, males think more about the practicality of the product and feel regret if the purchased product has no use or is less beneficial. Marketers could benefit from this conclusion in market segmentation, targeting and marketing planning programs.

As regards bank-card payment and sales promotion, the research findings demonstrated a positive association of bank-card payment, but not of sales promotion, with unplanned buying, validating the findings of O'Guinn \& Faber (1989), d'Atous (1990), Magee (1994), Roberts \& Martines (1997), Roberts (1998), Roberts \& Jones (2001), Park \& Burns (2005), and Phau \& Woo (2008). Bank-card payment association can be attributed to the high credit limit of these cards. Using bank cards in the process of buying from retail stores, the consumer becomes free of payment limits. The ceiling of expenditure becomes as high as the balances of money these bank cards allow. This situation requires from the Saudi Arabian Monetary Agency to mandate banks in Saudi Arabia not to increase credit limits associated with the issuance of credit cards. There is no doubt that the banks' desire to earn profit encourages them to expand credit limits of the cards. This strategy by banks contrasted with the marketing concept which focuses on consumer's benefit. Those bank strategies enable consumers to spend more than their financial capabilities, and make them owe the bank large debts. This is evidenced by the volume of credit card loans that amounted to S.R. 9.5 billion in fiscal year 2008 (Ministry of Economy and Planning, Saudi 
Arabia, 2011). On the other hand, consumers have to train themselves to be rational in using bank cards and become more involved in purchasing decision-making.

Sales promotion's insignificant association with unplanned buying can be attributed, in general, to the high income levels of Saudi consumers (the research sampling unit) compared to the other nationalities in Saudi Arabia. The high-income levels of Saudis make them less responsive to sales promotion activities of retail stores and more product-selective purchasers, so that, they are more likely to be loyal to particular brands. Saudi Marketers can take this into consideration when setting their marketing programs, giving more attention to product quality demanded by Saudi nationals.

\section{Limitations and Future Research}

The study is only limited to Saudi consumers in Riyadh, which limits the possibility of generalizing the results to Saudi consumers in other regions of the Kingdom with different economic, social and cultural conditions. The study also relies on a convenience sample of Saudi consumers in Riyadh city, because of the difficulty of obtaining a probability sample. Finally, the study measured the association of unplanned buying with post-purchase regret, and the association of sales promotion and bank-card payment with unplanned buying. The study examined the impact of family income and gender on the relationship between unplanned buying and post-purchase regret. Hence, it does not include any other variables that could have an impact on both unplanned buying and post-purchase regret or the relationship between them. So, future studies can investigate other variables that might be associated with both post-purchase regret or unplanned buying and their relationship antecedents.

\section{Acknowledgements}

The author extends his appreciation to the Deanship of Scientific Research at King Saud University, for funding the study through the Research Center. The author also expresses his gratitude to Dr. Ahmed Ali Soliman, professor of marketing at the College of Business Administration, King Saud University for giving his valuable insights in finalizing the paper.

\section{References}

Aiken, L. S., \& West, Stephen G. (1991). Multiple Regression: Testing and Interpreting Interactions. Sage publications, thousand Oaks, CA.

Bauer, R. A. (1960). Consumer Behavior as Risk taking in Hancock, R.S. ed., Dynamic Marketing for a Changing World. Proceedings of the $43^{\text {rd }}$ National Conference of the American Marketing Association, American Marketing Association, Chicago, IL.

Berman, B., \& Evans, J. R. (1995). Retail Management: a Strategic Approach. Prentice-Hall, Ypper Saddle River, NJ.

Blacetis, E., \& Dunning, D. (2007). Cognitive Dissonance and the Perception of Natural Environments. Psychology Science, 18(10), 917-921. http://dx.doi.org/10.1111/j.1467-9280.2007.02000.x

Blattberg, R. C. \&Neslin, S. C. (1990). Sales Promotion: Concepts, Methods, and Strategies. Prentice-Hall, Englewood Cliffs, NJ.

Block, L. G., \& Morwitz, V. G. (1999). Shopping Lists as an External Memory Aid for Grocery Shopping: Influences on List Writing and List Fulfillment. Journal of Consumer Psychology, 8(4), 343-375. http://dx.doi.org/10.1207/s15327663jcp0804_01

Boles, T. L. \& Messick, D. M. (1995). A Reverse Outcome Bias: the Influence of Multiple Reference Points on the Evaluation of Outcomes and Decisions. Organizational Behavior and Human Decision Processes, 61(3), 262-275. http://dx.doi.org/10.1006/obhd.1995.1021

Brassington, F., \& Pettite, S. (2006). Principles of Marketing (4th ed.). Pearson education, Harlow.

Bui, M., Krishen, A., \& Bates, K. (2011). Modeling Regret Effects on Consumer Post-purchase Decisions. European Journal of Marketing, 45(7/8), 1068-1090. http://dx.doi.org/10.1108/03090561111137615

Carter, O., Mills, B., \& Dnovan, R. (2009). The Effect of Retail Cigarette Pack Displays on Unplanned Purchase: Results from Immediate Post-purchase Interviews. TOB Control, 18(3), 218-221. http://dx.doi.org/10.1136/tc.2008.027870

Churchill, G. A. (1979). A Paradigm for Developing Better Measures of Marketing Constructs. Journal of Marketing Research, 16(1), 64-73. http://dx.doi.org/10.2307/3150876 
Cobb, C. J., \& Hoyer, W. D. (1986). Planned versus Impulsive Behavior. Journal of Retailing, 62(4), 384-409.

Cohen, M. J. (2007). Consumer Credit, Household Financial Management, and Sustainable Consumption. $\begin{array}{lllll}\text { International Journal of } & \text { Consumer }\end{array}$ http://dx.doi.org/10.1111/j.1470-6431.2005.00485.x

Coley, A., \& Burgess, B. (2003). Gender Differences in Cognitive and Affective Impulsive Buying. Journal of Fashion Marketing and Management, 7(3), 282-295. http://dx.doi.org/10.1108/13612020310484834

Coulton, A. (1996). Easy Credit for Students' Teachings Hard Lessons. American Banker, 161(200), 16-17.

d'Astous, A., \& Landeville, V. (2003). An Experimental Investigation of Factors Affecting Consumers' Perceptions of Sales promotions. European Journal of Marketing, 37(11), 1746-1761. http://dx.doi.org/10.1108/03090560310495447

d'Atous, A. (1990). An Inquiry into the Compulsive Side of Normal Consumers. Journal of Consumer Policy, 13(1), 15-31. http://dx.doi.org/10.1007/BF00411867

Deshpande, R., \& Krishnan, S. (1980). Consumer Impulsive Purchase and Credit Card Usage: an Empirical Examination using the log Linear Model. Advances in Consumer Research, 7, 792-795.

Dittmar, H., Beattie, J., \& Friese, S. (1996). Objects, Decision Consideration and Self-image in Men's and $\begin{array}{llll}\text { Woman's Impulsive } & \text { 187-206. }\end{array}$ http://dx.doi.org/10.1016/0001-6918(96)00019-4

Dittmar, H., Long, K., \& Bond, R. (2007). When a Better Self is Only a Button Click away: Associations between Materialistic Values, Emotional and Identity-related Buying Motives, and Compulsive Buying Tendency Online. Journal of Social and Clinical Psychology, 26(3), 334-361. http://dx.doi.org/10.1521/jscp.2007.26.3.334

Engel, J. F., Blackwell, R. D., \& Kollat, D. T. (1982). Consumer Behavior. Dryden Press, Chicago IL.

Faber R. J., \& O'Guinn, T. C. (1992). A Clinical Screener for Compulsive Buying. Journal of Consumer Research, 19(3), 459-469. http://dx.doi.org/10.1086/209315

Feinberg, R. A. (1986). Credit Cards as Spending Facilitating Stimuli: A Conditioning Interpretation. Journal of Consumer Research, 13(3), 348-356. http://dx.doi.org/10.1086/209074

Garcia, I. S., \& Perez, R. C. (2011). Effects of Dissatisfaction in Tourist Services: the Role of Anger and Regret. Tourism Management, 32(6), 1397-1406. http://dx.doi.org/10.1016/j.tourman.2011.01.016

Gbadamosi, A. (2009). Cognitive Dissonance: the Implicit Explication in Low-income Consumer's Shopping Behavior for "Low-involvement" Grocery Products. International Journal of Retail and Distribution Management, 37(12), 1077-1095. http://dx.doi.org/10.1108/09590550911005038

George, B. P., \& Vaoyuneyong, G. (2010). Impulsive Buying and Cognitive Dissonance: a Study Conducted among the Spring Break Student Shoppers. Young Customers, 11(4), 291-306. http://dx.doi.org/10.1108/17473611011093925

Gilbert, D. C., \& Jackaria, N. (2002). The Efficacy of Sales Promotions in U.K. Supermarkets: a Consumer View. International Journal of Retail and Distribution management, 30(6), 315-322. http://dx.doi.org/10.1108/09590550210429522

Heitmann, M., Lehmann, D. R., \& Herrmann, A. (2007). Choice Goal Attainment and Decision and Consumption Satisfaction. Journal of Marketing Research, 44(2), 234-250. http://dx.doi.org/10.1509/jmkr.44.2.234

Hoch, S. J., \& Loewentein, G. F. (1991). Time-inconsistent Preferences and Consumer Self-control. Journal of Consumer Research, 17(4), 492-507. http://dx.doi.org/10.1086/208573

Hoyer, W., \& McInnis, D. (2001). Consumer Behavior (2nd ed.). Houghton Mifflin Company, Boston, MA.

Inman, J. J., Dyer, J. S., \& Jia, J. (1997). A Generalized Utility Model of Disappointment and Regret Effects on Post-choice Valuation. Marketing Science, 16(2), 97-111. http://dx.doi.org/10.1287/mksc.16.2.97

Jaccard, J., Turrisi, R., \& Wan, C. K. (1990). Interaction Effects in Multiple Regression. Sage Publications, Thousand Oaks, C.A. 
Kowok, S., \& Uncles, M. (2005). Sales Promotion Effectiveness: the Impact of Consumers Differences at the Ethnic-group Level. Journal of Product and Brand Management, 14(3), 170-186. http://dx.doi.org/10.1108/10610420510601049

Lai, C. (2010). How Financial Attitudes and Practices Influence the Impulsive Buying Behavior of College and $\begin{array}{llll}\text { University Students. Social Behavior and Personality, 38(3), 373-380. } & \text {. }\end{array}$ http://dx.doi.org/10.2224/sbp.2010.38.3.373

Landman, J. (1987). Regret: a Theoretical and Conceptual analysis. Journal for the Theory of Social Behavior, 17(2), 135-160. http://dx.doi.org/10.1111/j.1468-5914.1987.tb00092.x

Landman, J. (1993). Regret: the Persistence of the Possible. Oxford University Press, New York, NY.

Lee, G. Y., \& Yi, Y. (2008). The effect of Shopping Emotions and Perceived Risk on Impulsive Buying: The Moderating role of Impulsiveness trait. Seoul Journal of Business, 14(2), 67-92.

Liao, S., Shen, Y., \& Chu, C. (2009). The Effects of Sales Promotion Strategy, Product Appeal and Consumer Traits on Reminder Impulsive Buying Behavior. International Journal of Consumer studies, 33(3), 274-284. http://dx.doi.org/10.1111/j.1470-6431.2009.00770.x

Lin, C., \& Lin, H. (2005). An Exploration of Taiwanese Adolescents' Impulsive Buying Tendency. Adolescence, 40(157), 215-223.

Loomers, G., \& Sugden, R. (1982). Regret Theory: an Alternative Theory of Rational Choice under Uncertainty. Economic Journal, 92(368), 805-824. http://dx.doi.org/10.2307/2232669

Magee, A. (1994). Compulsive Buying Tendency as a Predictor of Attitudes and Perceptions. Advances in Consumer Behavior Research, 21(1), 590-594.

Mai, N. T., Jung, K., Lantz, G., \& Loeb, G. (2003). An Exploratory Investigation into Impulsive Behavior in a Transitional Economy: a Study of Urban Consumers in Vietnam. Journal of International Marketing, 11(2), 13-35. http://dx.doi.org/10.1509/jimk.11.2.13.20162

Malhotra, N. K. (2007). Marketing Research: an Applied Orientation. Pearson Prentice Hall.

Mannix, M. (1999).The Credit Card Binge. U.S. News and World Report, 127, 9-89.

Mihic, M., \& Kursan, I. (2010). Assessing the Buying Behavior: Market Segmentation Approach. Management, 15(2), 47-66.

Ministry of Economy \& Planning. (2008). Ninth Development Plan 31/1432-35/1436H. Kingdom of Saudi Arabia, 278.

Mitchell, V., \& Walsh, G. (2004). Gender Differences in German Consumer Decision-making Styles. Journal of Consumer Behavior, 3(4), 331-346. http://dx.doi.org/10.1002/cb.146

Mueller A., Mitchell, J. E., Mertens, C., Mueller U., Sibermann, A., Burgard, M., \& de Zwaan, M. (2007). Compassion of Treatment Seeking Compulsive Buyers in Germany and the United States. Business Research and Therapy, 45(7), 1629-1638. http://dx.doi.org/10.1016/j.brat.2006.08.005

Muller A., Reinecker, H., Jacobi, R., \& De Zawaan, M. (2005). Pathological Buying: A Literature Review. Psychiatrische Praxis, 32(1), 3-12.

Ndubisi, N. O., \& Moi, C. T. (2006). Awareness and Usage of Promotional Tools by Malaysian Consumers: the Case of Low-involvement Products. Management Research News, 29(1), 28-40. http://dx.doi.org/10.1108/01409170610645420

Nicholas, J. A., Li, F., Roslow, S., Kranendonk, C. J., \& Mandakovic, T. (2001). Inter-American Perspectives from Mall shoppers: Chile-United States. Journal of Global Marketing, 15(1), 87-103. http://dx.doi.org/10.1300/J042v15n01_06

Norum, P. S. (2008). The Role of Time Preference and Credit Card usage in Compulsive Buying Behavior. $\begin{array}{lllll}\text { International Journal of } & \text { Consumer }\end{array}$ http://dx.doi.org/10.1111/j.1470-6431.2008.00678.x

O'Guin, T., \& Faber, R. (1989). Compulsive Buying: A Phenomenological Exploration. Journal of Consumer Research, 16(2), 147-157.

Park, H., \& Burns, L. (2005). Fashion Orientation, Credit Card use, and Compulsive Buying. Journal of Consumer Marketing, 22(3), 135-141. http://dx.doi.org/10.1108/07363760510595959 
Peattie, S., \& Peattie, K. (2003). Sales Promotion (Baker, M. J. ed.). Butterworth-Heinemann, Oxford.

Phau, I., \& Woo, C. (2008). Understanding Compulsive Buying Tendencies among Young Australians: The Roles of Money Attitude and Credit card Usage. Marketing Intelligence \& Planning, 26(5), 441-458. http://dx.doi.org/10.1108/02634500810894307

Pirog III, S. F., \& Roberts, J. A. (2007). Personality and Credit Card Misuse among College Students: The Mediating Role of Impulsiveness. Journal of Marketing Theory and Practice, 15(1), 65-77. http://dx.doi.org/10.2753/MTP1069-6679150105

Pooler, J. A., \& Pooler, J. (2003). Why We Shop: Emotional Rewards and Retail Strategies. Praeger: West Port, Connecticut, USA.

Ritzer, G. (1995). Expressing America: A Critique of the Global Credit card Society. Thousand Oaks, CA: Pine Forge Press.

Roberts, J. A. (1998). Compulsive Buying among College Students: an Investigation of Antecedents, Consequences and Implications for Public Policy. The Journal of Consumer Affairs, 32(2), 295-319.

Roberts, J. A., \& Jones, E. (2001). Money Attitudes, Credit Card Use and Compulsive Buying among American College Students. Journal of Consumer Affairs, 35(2), 213-240. http://dx.doi.org/10.1111/j.1745-6606.2001.tb00111.x.

Roberts, J., \& Martines, C. (1997). The Emerging Consumer Culture in Mexico: An Exploratory Investigation of Compulsive Buying in Mexican Young Adults. Journal of International Consumer Marketing, 10(1/2), $7-31$.

Rook, D. W., \& Hotch, Stephen, J. (1985). Consuming Impulsive. Advances in Consumer Research, 12(December), 23-27.

Rook, D., \& Fisher, R. J. (1995). Trait and Normative Aspects of Impulsive Buying Behavior. Journal of Consumer Research, 22(3), 305-313. http://dx.doi.org/10.1086/209452

Schembari, J. (2000). New College Sticker Shock: Junior's Credit Card Bill. The New York Times. February, 27.

Shankar, A., Cherrier, H., \& Canniford, R. (2006). Consumer Empowerment: A Foucauldian Interpretation. European Journal of Marketing, 40(9), 1013-1030. http://dx.doi.org/10.1108/03090560610680989

Shi, Y., Cheung, K., \& Prendergast, G. (2005). Behavioral Response to Sales Promotion Tools: a Hong Kong Study. International Journal of advertising, 24(4), 467-486.

Shoham, A., \& Brencic, M. (2003). Compulsive Buying Behavior. Journal of Consumer Marketing, 20(2), 127-138. http://dx.doi.org/10.1108/07363760310464596

Simpson, P. M., Siguaw, J. A., \& Cadogan, J. W. (2008). Understanding the Consumer Propensity to Observe. European Journal of Marketing, 42(1), 196-221. http://dx.doi.org/10.1108/03090560810840970

Smith, J. B., \& Bristor, J. M. (2006). Uncertainty Orientation: Explaining Differences in Purchase Involvement and External Search. Psychology and Marketing, 11(6), 587-607 .http://dx.doi.org/10.1002/mar.4220110606

Solomon, M. R. (2002). Consumer Behavior. Prentice Hall, Engelwood Cliffs, N.J.

Solomon, M. R. (2004). Consumer Behavior (6th ed.). Prentice Hall, upper saddle river, N.J.

Sweeney, J. C., Hausknecht, D., \& Souter, G. N. (2000). Cognitive Dissonance after Purchase: a $\begin{array}{lllll}\text { Multidimensional Scale. } \quad \text { Psychology \& } \quad \text { Marketing, } & \text { 17(5), }\end{array}$ http://dx.doi.org/10.1002/(SICI)1520-6793(200005)17:5<369::AID-MAR1>3.0.CO;2-G

Takunga, W. (1992). The use and Abuse of Consumer Credit: Application of Psychological Theory and $\begin{array}{llll}\text { Research. Journal of Economic } & \text { Psychology, }\end{array}$ http://dx.doi.org/10.1016/0167-4870(93)90004-5

Taylor, S. E., \& Schneder, S. K. (1998). Coping and Simulation of Events. Social Cognition, 7(2), 174-194. http://dx.doi.org/10.1521/soco.1989.7.2.174

Tsiros, M., \& Mittal, V. (2000). Regret: A Model of its Antecedents and Consequences in Consumer Decision Making. Journal of Consumer Research, 26(4), 410-417. http://dx.doi.org/ 10.1086/209571

Undrill, P. (1999). We Buy: the Science of Shopping. Simon Schuster, New York, NY. 
Venkataman, M. P. (2006). Involvement and Risk. Psychology and Marketing, 6(3), 229-247. http://dx.doi.org/10.1002/mar.4220060306

Verplanken, B., \&Herabadi, A. (2001). Individual Differences in Impulsive Buying Tendency: Feeling and not Thinking. European Journal of Personality, 15(1), 71-83. http://dx.doi.org/10.1002/per.423

Wakefield, M., Germain, D., \& Henriksen, L. (2008). The Effect of Retail Cigarette Pack Displays on Impulsive Purchase. Addiction, 103(2), 322-328. http://dx.doi.org/10.1111/j.1360-0443.2007.02062.x

Wang, J., \& Xiao, J. J. (2009). Buying Behavior, Social Support and Credit Card Indebtedness of College Students. International Journal of Consumer Students, 33(1), 2-10. http://dx.doi.org/ 10.1111/j.1470-6431.2008.00719.x

Wood, M. (1998). Socio-Economic Status, Delay of Gratification and Impulsive Buying. Journal of Economic Psychology, 19(3), 295-320. http://dx.doi.org/10.1016/S0167-4870(98)00009-9

Zeelenberg, M., \& Pieters, R. (1999). Comparing Service Delivery to What Might Have Been. Journal of Service Research, 2(1), 86-97. http://dx.doi.org/10.1177/109467059921007

Zeelenberg, M., \& Pieters, R. (2007). A Theory of Regret Regulation. Journal of Consumer Psychology, 17(1), 3-18. http://dx.doi.org/10.1207/s15327663jcp1701_3 